Available online at GSC Online Press Directory

GSC Advanced Research and Reviews e-ISSN: 2582-4597, CODEN (USA): GARRC2

Journal homepage: https://www.gsconlinepress.com/journals/gscarr

(SHORT COMMUNICATION)

\title{
An essay: John Locke's views on education
}

\author{
Alma E. Nacua*, Bernadette L. Corsame, Angelita L. Dela Cruz and Noami D. Solano \\ College of Arts and Sciences, Universidad de Manila, One Mehan Garden Ermita Manila, Philippines.
}

Publication history: Received on 14 December 2020; revised on 22 December 2020; accepted on 24 December 2020

Article DOI: https://doi.org/10.30574/gscarr.2020.5.3.0127

\begin{abstract}
Education means shaping according to each individual's temperament and skills, exercised without brutality, but in a rigorous and pragmatic manner. The purpose of this essay is to explain Locke's educational theory. Conclusion: Education of the people should have moral training, good breeding, Wisdom, useful knowledge.
\end{abstract}

Keywords: Virtue

\section{Introduction}

As the father of liberalism Locke believed that the purpose of education was to produce an individual with a sound mind in a sound body so as to better serve his country. Locke thought that the content of education ought to depend upon one's station in life. The common man only required moral, social, and vocational knowledge. However, the education of gentlemen ought to be of the highest quality. People must serve his country in a position of leadership. For people, Locke believed that he/she must have thorough knowledge of his own language. Locke held the Puritans belief that the content of the curriculum must serve some practical end. John Locke's recommended the introduction of contemporary foreign languages, history, geography, economics, math and natural science.

\section{Locke's Educational Theory}

This conception on the origins of knowledge is older, being also present in a specific form in the Greek philosophy, viz. in Aristotle's "De anima" ("On the Soul"), 429b29-430a2, who could have taken it from his magister Plato (see, in this respect, the Dialogues "Theaetetus" and "Philebus"): "Or in the way that to be acted upon according to something common has been distinguished before, that the mind is in potentiality somehow the intelligible objects but in actuality nothing until it thinks. Thus it must be just as in a tablet in which nothing exists in actuality written down, which occurs in the case of the mind" Polansky (2007).

If the at birth the child's mind zero ideas, then as an educator has a major role in shaping the personality of the students. Whom he transforms into a model of human behavior. Teaching the students, the step by step procedure just like climbing a ladder to the best of their abilities. Education plays an important role in shaping moral development and social integration of a person. Education would mean molding an individual character, temperament and skills, practice without violence, it can be difficult but realistic and relevant and most importantly it should be attainable. To Speak about education, it talks about discipline, morally good and the ability to reject immoral act, appreciate personal values of what is good and what is bad. Student should be taught to master and listen to instinctual side. As an individual a person is strong but it does not mean to dominate others. This is clearly a specific trait of the Protestant puritan ethics, mainly evinced by the German sociologist Max Weber in his famous "The Protestant Ethic and the Spirit of Capitalism"

\footnotetext{
* Corresponding author: Alma E. Nacua

College of Arts and Sciences, Universidad de Manila, One Mehan Garden Ermita Manila, Philippines.
}

Copyright (C) 2020 Author(s) retain the copyright of this article. This article is published under the terms of the Creative Commons Attribution Liscense 4.0. 
(1905) Genuine education may not be dissociated from the ideal of a freely assumed asceticism, who makes man conscientious, industrious, virtuous, able to resist the hardships of life, receptive to spiritual realities and therefore the needs of his fellow humans. People usually train their pets when young, so that to be able to use them properly, yet they are not wise enough to do the same with their offspring, unreasonably allowing the children's perverse habits to become more rooted as they grow M. Androne (2014) Grass is harder to pull out from a dry land — if the bad habits are not corrected at a tender age, the risk is they can never be completely removed (Adamson, 1922, pp. 29). To Locke is very particular in disciplining students forming a moral character. To discipline is a tool but does not mean brutality, forbidding or tyrannical attitude. As a parents and educators are encouraging to be gentle in relation to the young students. Dealing with different individual person cannot impose the same discipline. This psychosomatic health actually constitutes a privileged objective of any genuine educational approach. Those who are born physically and spiritually strong are a minority, as most of our fellow humans are good or bad, useful or useless, according to the education they received. People are not equal, as they do not benefit from the same education. Although the mind is the most important part of our being, it is not a good idea to neglect the body: through his robust physical constitution man may successfully cope with the daily activities and fatigue, bravely facing all sorts of hardships and adapting to his environment M. Androne (2014) In the Christian vision, virtue is inextricably linked to piety, and from the very beginning religion itself has promoted the ideal of a virtuous life laid on the solid foundation of observing the Ten Commandments. Hence the idea that religion disposes of an important social and political role as it constantly urges towards assuming responsibilities in the public and private sphere M. Androne (2014) Virtue appears as the defining quality of an individual, making him most sensitive to the needs of the others. "This ethic, particularly in its elements of liberality and civility, will be connected to Locke's own frequently avowed social identity as a gentleman who was concerned at many points in his life with emphasizing the responsibilities of service to others involved in a 'Gentleman's calling', and with performing these duties himself" (Marshall, 1994, pp. xvii). Virtue is similar to honor and justice, a person showing a high moral standard. Anyone cannot live without being virtuous. Acquiring this virtues traits is through formal education. Being virtuous is living a morally correct life. Understanding the action of speaking on a very positive way of not hurting others feelings. The ideal virtuous person is not dogmatic or driven by ideology but knows how to integrate the best ideas of the best thinkers and to act accordingly, leading by example and not by edict. The ideal virtuous person demonstrates authenticity and moral authority. Aristotle would add that the ideal virtuous person has the right motives, traits, and commitments.

\section{Discussion}

Locke proposed the following for the education of the people: (a) moral training. All Christians must learn to live virtuously. (b) Good breeding. The people must develop the poise, control and outward behavior of excellent manners, education must aim therefore at developing correct social skills. (c) wisdom. The people ought to be able to apply intellectual and moral knowledge in governing his practical affairs. (d) useful knowledge. The people must receive education which will lead to a successful life in the practical affairs of the society, as well as that which leads to the satisfaction derived from scholarship and good books.

\section{Conclusion}

Based on Locke's theory Education of the people should have proper moral training, good breeding, Wisdom, useful knowledge.

\section{Compliance with ethical standards}

\section{Acknowledgments}

The researchers would like to thank CHED for funding this research study and for the UDM administration for motivation to do the research.

\section{Disclosure of conflict of interest}

No conflict of interest

\section{References}

[1] Adamson JW. (ed.) The Educational Writings of John Locke. Cambridge: University Press. 1922.

[2] Marshall J. John Locke: Resistance, Religion and Responsibility. Cambridge: Cambridge University Press. 1994. 
GSC Advanced Research and Reviews, 2020, 05(03), 098-100

[3] Max Weber. The Protestant Ethic and the Spirit of Capitalism, Public Domain (P)2017 Cherry Hill Publishing, LLC. 1905.

[4] Mihai Androne. Notes on John Locke's views on education. Procedia - Social and Behavioral Sciences 137. 2014; $74-79$.

[5] Polansky R. Aristotle’s De anima. Cambridge: Cambridge University Press. 2007. 